\title{
EFFECTS OF DIVALENT CATIONS ON THE CONVERSION OF BACTERIOPHAGE M13 AND $\Phi$ X174 DNAS TO THEIR REPLICATIVE FORMS BY EXTRACTS OF ESCHERICHIA COLI
}

\author{
MIEKO HIGASHI, FUMIAKI ITO, AND YUKITO MASAMUNE \\ Department of Pharmaceutical Sciences, Kanazawa University, \\ Takara-machi, Kanazawa-city, Ishikawa, Japan
}

(Received January 14, 1980)

The conversion of single-stranded circular DNA of bacteriophage M13 or $\phi X 174$ to the double-stranded form by cell-free extracts of Escherichia coli requires $\mathrm{Mg}^{2+}$ as a cofactor. In this report, it was examined whether any other divalent cation could substitute for $\mathrm{Mg}^{2+}$ as a cofactor at the replication of these DNAs. The results showed that $\mathrm{Mn}^{2+}, \mathrm{Co}^{2+}, \mathrm{Sr}^{2+}$, and $\mathrm{Ba}^{2+}$ could replace $\mathrm{Mg}^{2+}$. The replacement, however, induced some abnormal synthesis of DNA. The DNA synthesized with $\mathrm{Mn}^{2+}$ or $\mathrm{Sr}^{2+}$ contained several interruptions in the synthesized strand. The synthesis of DNA seems to be initiated at several points on the identical template. The DNA synthesized with $\mathrm{Mn}^{2+}$, $\mathrm{Co}^{2+}$, or $\mathrm{Sr}^{2+}$ had plaque-forming ability, and the product synthesized with $\mathrm{Mn}^{2+}$, or $\mathrm{Co}^{2+}$ but not with $\mathrm{Sr}^{2+}$, showed high frequencies of mutation. Although the synthesis of $\phi$ X174 DNA was not inhibited by rifampicin when $\mathrm{Mg}^{2+}$ was used as a cofactor, it was inhibited when $\mathrm{Mn}^{2+}$ or $\mathrm{Sr}^{2+}$ was used instead of $\mathrm{Mg}^{2+}$.

All known DNA polymerases [EC 2.7.7.7] require $\mathrm{Mg}^{2+}$ as divalent cation for activity (1). Manganese ion which is a potent mutagen (2-4) could usually substitute for $\mathrm{Mg}^{2+}$ for their activities. The fidelity of DNA replication was reduced with $\mathrm{Mn}^{2+}(5-8)$. Sirover and LoeB $(9,10)$ suggested that all of the metal mutagens or carcinogens would affect the activities of DNA polymerases and induce the perturbations in the fidelity of DNA synthesis.

The effects of $\mathrm{Mn}^{2+}$ and some other metals were examined with DNA polymerase I of Escherichia coli $(E$. coli). The results suggested that the mutagenic metals stimulated the incorporation of non-complementary nucleotides into DNA $(6,8,11,12)$. BERG $(13)$ discovered that ribonucleotide residues could be incorporated into DNA chains by DNA polymerase I of $E$. coli, when synthesis was carried out in the presence of $\mathrm{Mn}^{2+}$ in place of $\mathrm{Mg}^{2+}$. 
Kornberg and Gefter (14), and Livingston and Richardson (15) reported that $\mathrm{Mn}^{2+}$ could substitute for $\mathrm{Mg}^{2+}$ for the activity of purified DNA polymerase III which is an essential enzyme for the replication of DNA $(16,17)$, but the analysis of the product has not been carried out.

Cell-free extracts prepared from $E$. coli cells lacking DNA polymerase I can convert single-stranded circular DNA of phage M13 or $\phi$ X174 to the doublestranded circular form in a reaction which requires DNA polymerase III and other host proteins $(18-20)$. We have used such a system to investigate the effects of divalent cations on the synthesis of phage DNA. The results show that the synthesis of DNA was observed with $\mathrm{Mn}^{2+}, \mathrm{Co}^{2+}, \mathrm{Sr}^{2+}$, and $\mathrm{Ba}^{2+}$. The DNA synthesized with $\mathrm{Mn}^{2+}$ or $\mathrm{Sr}^{2+}$ had some breaks in the products. When plaque-forming activities of these products were assayed on the cells treated with $\mathrm{CaCl}_{2}$, enhanced mutation frequencies were observed with the DNA synthesized with $\mathrm{Mn}^{2+}$ and $\mathrm{Co}^{2+}$.

\section{MATERIALS AND METHODS}

Bacterial and phage strains. E. coli $\mathrm{H} 560$ (pol A, end I, thy, and str) was obtained from R. Okazaki and was used to prepared the cell-free extracts. $E$. coli $\mathrm{HfrC}$ was used to grow phage M13. E. coli HF4704 (su, hcr, thy, and $\left.\phi X^{\mathrm{s}}\right)$ and E. coli HF4714 $\left(s u^{+}\right.$, thy, $\left.\phi X^{\mathrm{s}}\right)$ which were used to grow $\phi \mathrm{X} 174 a m 3$, and $\phi$ X174am 3 were obtained from C. C. Richardson. Phage M13 was obtained from D. Pratt.

Chemicals. Divalent metal salts: $\mathrm{MgCl}_{2}, \mathrm{CaCl}_{2}, \mathrm{CrCl}_{2}, \mathrm{MnCl}_{2}, \mathrm{CoCl}_{2}$, $\mathrm{NiCl}_{2}, \mathrm{CuCl}_{2}, \mathrm{ZnCl}_{2}, \mathrm{SrCl}_{2}, \mathrm{CdCl}_{2}, \mathrm{BaCl}_{2}, \mathrm{HgCl}_{2}$, and $\mathrm{Pb}\left(\mathrm{NO}_{3}\right)_{2}$ were best-grade chemicals purchased from Wako Pure Chemical Industries, Ltd. Cesium sulfate was purchased from Nakarai Chemicals, Ltd. Ribo- and deoxyribonucleoside triphosphates and lysozyme were purchased from Seikagaku Kogyo Co., Ltd. Nucleotides were purified by chromatography on DEAE-Sephadex A25 as described by MASAMUNE and RichARDSON (21). All nucleotides were purified as ammonium salts. Rifampicin was given by M. Kumagai (Institute of Microbial Chemistry, Tokyo). [ $\left.{ }^{3} \mathrm{H}\right]$-thymidine $(20 \mathrm{Ci} / \mathrm{mmol})$ and $\left[{ }^{3} \mathrm{H}\right]$-deoxythymidine triphosphate $(60 \mathrm{Ci} / \mathrm{mmol})$ were the products of New England Nuclear.

Growth of phages and preparation of their DNA. Phages M13 and $\phi \mathrm{X} 174 a m 3$ were grown as described previously $(22,23)$. Phage M13 labelled with $\left[{ }^{3} \mathrm{H}\right]$ thymidine was prepared as described previously (23). The DNAs were extracted with phenol from these phages and were dissolved in $10 \mathrm{~mm}$ Tris- $\mathrm{HCl}$ buffer $(\mathrm{pH}$ 7.6) containing $0.1 \mathrm{~mm}$ EDTA. The final concentration of these DNAs was adjusted to $2 \mu \mathrm{mol}$ of nucleotide per $\mathrm{ml}$. Final concentration of $\left[{ }^{3} \mathrm{H}\right]$-DNA was $0.26 \mu \mathrm{mol} / \mathrm{ml}, 1.7 \times 10^{5} \mathrm{cts} / \mathrm{min} / \mu \mathrm{mol}$. The concentration of DNAs of phages M13 and $\phi$ X174 was calculated from the absorbance measured at $260 \mathrm{~nm}$ (22).

Preparation of cell-free extract. A cell-free extract from E. coli $\mathrm{H} 560$ was 
prepared following the method of W. T. WICKNER et al. (19).

Conversion of single-stranded DNA to double-stranded form. The reaction mixture $(50 \mu \mathrm{l})$ contained $20 \mathrm{~mm}$ Tris- $\mathrm{HCl}$ buffer (pH 7.6), $30 \mathrm{~mm} \mathrm{NaCl}, 250 \mu \mathrm{M}$ each of ATP, CTP, GTP, and UTP, $500 \mu \mathrm{M}$ each of dATP, dCTP, dGTP, and $250 \mu \mathrm{M}$ of $\left[{ }^{3} \mathrm{H}\right]$-dTTP $(30 \mathrm{cts} / \mathrm{min} / \mathrm{pmol}), 5 \mathrm{nmol}$ of phage DNA and $25 \mu \mathrm{l}$ of cell extracts. Various concentration of divalent cations were added to the above reaction mixture. After incubation at $30^{\circ}$ for $30 \mathrm{~min}$, the reaction was stopped by the addition of $1 \mathrm{ml}$ of $1 \mathrm{~N} \mathrm{HCl}-0.1 \mathrm{M}$ pyrophosphate. The acid-insoluble radioactivity was determined as described previously (23). The effect of rifampicin on the synthesis of DNA was examined by adding $1 \mu \mathrm{l}$ of rifampicin $(0.5 \mathrm{mg} / \mathrm{ml})$ to the reaction mixture prior to the incubation.

Quantification of the concentration of magnesium in the extracts of E. coli H560. The concentration of magnesium in the cell-free extracts of $E$. coli $\mathrm{H} 560$ was quantified following the standard procedure of atomic absorption spectrophotometry (flame method) using a Hitachi 170-10 atomic absorption spectrophotometer at $285.2 \mathrm{~nm}$. The measurements were performed with the help of Dr. K. Hayakawa in our Department.

Velocity sedimentation and density gradient centrifugation.

Sucrose gradient centrifugation: Analysis of DNA by sucrose gradient centrifugation was performed as described previously (23).

$\mathrm{Cs}_{2} \mathrm{SO}_{4}-\mathrm{HgCl}_{2}$ density gradient centrifugation: The analysis of DNA with $\mathrm{Cs}_{2} \mathrm{SO}_{4}-\mathrm{HgCl}_{2}$ density gradient centrifugation was performed following the method of OISHI (24). After the synthesis of DNA for $30 \mathrm{~min}$ at $30^{\circ}, 20 \mu 1$ of $0.2 \mathrm{M}$ EDTA and $20 \mu \mathrm{l}$ of sodium lauroyl sarcosinate $(10 \%$ solution $)$ were added to the reaction mixture $(200 \mu \mathrm{l})$ which was then extracted several times with chloroform-isoamylalcohol $(24: 1, \mathrm{v} / \mathrm{v})$ to remove proteins. The water layer was dialysed against $20 \mathrm{~mm} \mathrm{Na}_{2} \mathrm{SO}_{4}-10 \mathrm{~mm} \mathrm{Na}_{2} \mathrm{~B}_{4} \mathrm{O}_{7}$ buffer (pH 9.4). After dialysis, $50 \mu 1$ of the sample ( 3 nmols of DNA) and $50 \mu \mathrm{l}$ of phage T7 DNA $(60 \mathrm{nmol})$ dissolved in the same buffer were mixed and $\mathrm{Cs}_{2} \mathrm{SO}_{4}$ dissolved to saturation in the above buffer was added to make the density of the solution $\rho=1.626$. One-tenth $\mathrm{ml}$ of $0.15 \mathrm{mM} \mathrm{HgCl}_{2}$ was further added to make $\left[\mathrm{Hg}^{2+}\right] /[\mathrm{DNA}]=0.25$. The density of the solution was finally adjusted to $\rho=1.570$ by the addition of $\mathrm{H}_{2} \mathrm{O}$. The mixture was centrifuged at $35,000 \mathrm{rpm}$ in a Hitachi RP55TA rotor for $40 \mathrm{hr}$ at $5^{\circ}$. The acid-insoluble radioactivities were measured after collecting the samples from the bottom of the tube. $\left[{ }^{3} \mathrm{H}\right]-\mathrm{M} 13$ DNA (single-strand) and $\left[{ }^{3} \mathrm{H}\right]-\mathrm{M} 13$ (duplex) which was synthesized with $\mathrm{Mg}^{2+}$ in the extracts of E. coli $\mathrm{H} 560$ under the standard condition (23) were spun in parallel as density markers.

Other methods. Assay of the plaque-forming ability of DNA synthesized with various metal ions: DNA synthesized with $\mathrm{Mg}^{2+}, \mathrm{Mn}^{2+}, \mathrm{Co}^{2+}$, or $\mathrm{Sr}^{2+}$ and with M13 DNA as template was centrifuged in neutral sucrose gradient to purify the duplex molecule, the plaque-forming ability of which was measured by plating with E. coli $\mathrm{HfrC}$ treated with $\mathrm{CaCl}_{2}$ following the method of COHEN et al. (25). 
Protein was determined by the method of LowRy et al. (26) using bovine albumin (product of Miles Laboratories, Ltd.) as a standard.

\section{RESULTS}

Concentration of magnesium in the extracts of E. coli $H 560$

Since $\mathrm{Mg}^{2+}$ is the natural cofactor of DNA polymerase, magnesium in the extracts would disturb the measurements of the activities of metal ions on the synthesis of DNA. The concentration of magnesium in the extracts of $E$. coli H560 grown in L-broth was quantified by atomic absorption spectrophotometry. It was about $6 \mathrm{~mm}$ or $0.4 \mu \mathrm{mol} / \mathrm{mg}$ protein.

\section{Effects of divalent metal salts on the synthesis of DNA}

The synthesis of DNA was measured with various divalent metal salts using phage M13 or $\phi$ X174 DNA as template. The result is shown in Table 1 . The synthesis was observed with $\mathrm{MgCl}_{2}, \mathrm{MnCl}_{2}, \mathrm{CoCl}_{2} \mathrm{SrCl}_{2}$, and $\mathrm{BaCl}_{2}$. Little synthesis was recognized with other salts $\left[\mathrm{CaCl}_{2}, \mathrm{CrCl}_{2}, \mathrm{NiCl}_{2}, \mathrm{CuCl}_{2}, \mathrm{ZnCl}_{2}, \mathrm{CdCl}_{2}\right.$, $\mathrm{HgCl}_{2}$, and $\left.\mathrm{Pb}\left(\mathrm{NO}_{3}\right)_{2}\right]$. Figures $1 \mathrm{a}$ and $1 \mathrm{~b}$ show the effects of concentration of the former metal salts on the synthesis of DNA with M13 and $\phi$ X174 DNA as template, respectively. The optimal concentration was specific with each salt and the concentration was almost the same with both templates.

Table 1. The effect of metal salts on the synthesis of DNA in the extracts of $E$. coli polA.

\begin{tabular}{lccc}
\hline Compound & $\begin{array}{c}\text { Concentration } \\
\text { of salt (mM) }\end{array}$ & \multicolumn{2}{c}{ dTMP incorporated (pmol) } \\
\cline { 3 - 4 } None & - & 0.0 & $\phi$ X174 DNA \\
$\mathrm{MgCl}_{2}$ & 7.5 & 46.5 & 0.0 \\
$\mathrm{MnCl}_{2}$ & 5.0 & 78.0 & 33.0 \\
$\mathrm{CoCl}_{2}$ & 1.5 & 23.0 & 116.0 \\
$\mathrm{SrCl}_{2}$ & 10.0 & 20.7 & 16.0 \\
$\mathrm{BaCl}_{2}$ & 7.5 & 48.4 & 96.0 \\
\hline
\end{tabular}

The reaction mixture containing various salt and phage M13 or $\phi$ X174 DNA as template was incubated at $30^{\circ}$ for $30 \mathrm{~min}$, and the acid-insoluble radioactivity was measured.

Phage M13 DNA as template (Fig. 1a). The amount of synthesis of DNA with $\mathrm{Mn}^{2+}$ exceeded that with $\mathrm{Mg}^{2+}$ at the optimal concentration, and the synthesis was strongly inhibited at higher concentration than optimum. The synthesis with $\mathrm{Co}^{2+}$ was poor and the optimal concentration was low. The concentration of $\mathrm{Sr}^{2+}$ required for its maximal activity was higher than with other metals. All of these syntheses were inhibited by the addition of rifampicin, a specific inhibitor of RNA polymerase (27). 


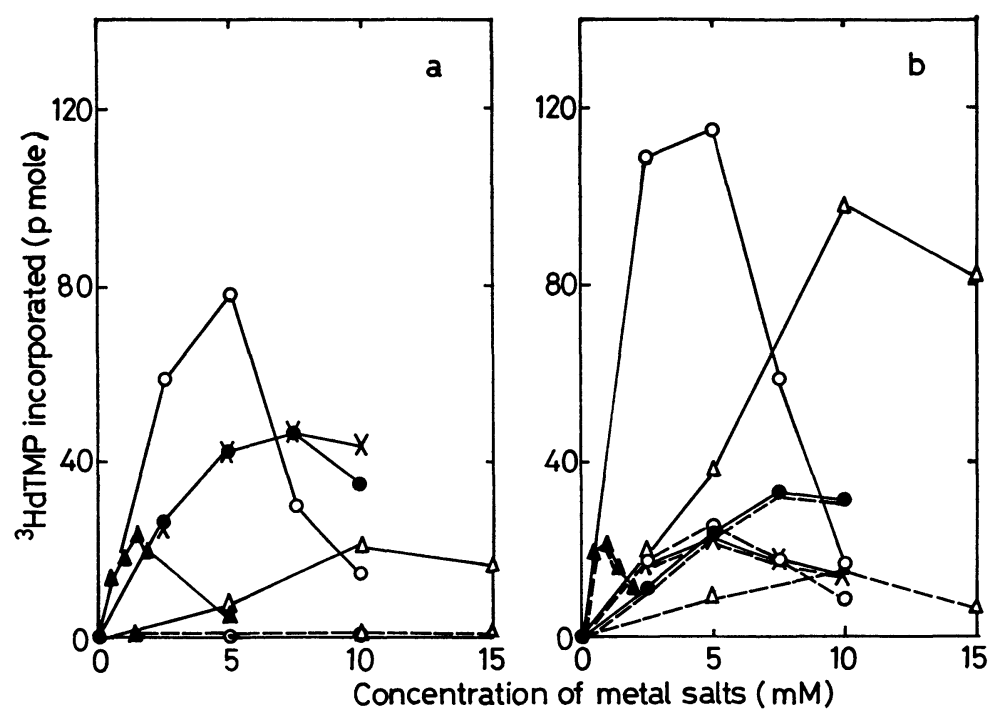

Fig. 1. Effect of the concentration of metal salts $\left(\mathrm{MgCl}_{2}, \mathrm{MnCl}_{2}, \mathrm{CoCl}_{2}, \mathrm{SrCl}_{2}\right.$, and $\mathrm{BaCl}_{2}$ ) on the synthesis of DNA.

Dependence of the synthesis of DNA on the concentration of divalent cations was measured by the incorporation of $\left[{ }^{3} \mathrm{H}\right]$-dTMP into acid-insoluble fraction. The reaction mixture was incubated at $30^{\circ}$ for $30 \mathrm{~min}$. a) Phage M13 DNA was used as template. b) Phage $\phi \mathrm{X} 174 \mathrm{DNA}$ was used as template. Dotted lines (---) are the results with rifampicin of the corresponding symbols. - synthesis of DNA with $\mathrm{MgCl}_{2} ; \mathrm{O}$, synthesis of DNA with $\mathrm{MnCl}_{2} ; \mathbf{\Delta}$, synthesis of DNA with $\mathrm{CoCl}_{2} ; \triangle$, synthesis of DNA with $\mathrm{SrCl}_{2}$; $\times$, synthesis of DNA with $\mathrm{BaCl}_{2}$.

Phage $\phi X 174$ as template (Fig. 1b). The amount of synthesis of DNA with $\mathrm{Mn}^{2+}$ or $\mathrm{Sr}^{2+}$ far exceeded that with $\mathrm{Mg}^{2+}$ at the optimal concentration. The synthesis was partially inhibited by rifampicin when $\mathrm{Mn}^{2+}$ or $\mathrm{Sr}^{2+}$ was used as a cofactor, but it was resistant when $\mathrm{Mg}^{2+}, \mathrm{Co}^{2+}$, or $\mathrm{Ba}^{2+}$ was used.

It would be noteworthy that no DNA synthesis was detected without addition of any divalent metals with either template, even if extracts supplied about $3 \mathrm{~mm}$ magnesium to the reaction mixture.

\section{Effect of concentration of template DNA}

The effect of concentration of template DNA on the synthesis of DNA was examined and the results are shown in Figs. $2 \mathrm{a}$ and $2 \mathrm{~b}$.

Phage M13 DNA as template (Fig. 2a). When $\mathrm{Mg}^{2+}, \mathrm{Co}^{2+}, \mathrm{Sr}^{2+}$, or $\mathrm{Ba}^{2+}$ was used as a cofactor, the amount of DNA synthesis levelled off at the concentration of 20-30 $\mu \mathrm{M}$ of template. With $\mathrm{Mn}^{2+}$, however, the synthesis increased with increasing concentration of template up to $100 \mu \mathrm{M}$.

Phage $\phi X 174$ DNA as template (Fig. 2b). The amount of DNA synthesized with $\mathrm{Mn}^{2+}$ or $\mathrm{Sr}^{2+}$ increased with increasing concentration of template. The 


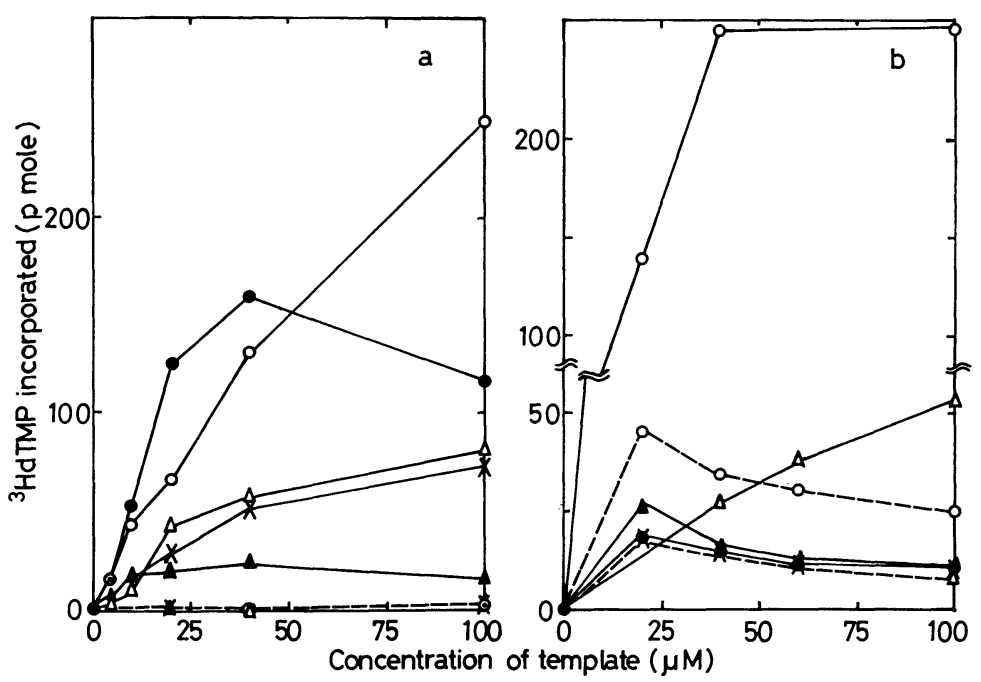

Fig. 2. Effect of the concentration of template DNA on the synthesis of DNA. Synthesis of DNA was measured by changing the concentration of template molecule at the optimal concentration of each metal salt (7.5 mM of $\mathrm{MgCl}_{2}$ or $\mathrm{BaCl}_{2}, 5 \mathrm{mM}$ of $\mathrm{MnCl}_{2}, 1.5 \mathrm{~mm}$ of $\mathrm{CoCl}_{2}$, and $10 \mathrm{~mm}$ of $\mathrm{SrCl}_{2}$ ). a) Phage M13 DNA as template. b) Phage $\phi \mathrm{X} 174$ DNA as template. The assay conditions of the synthesis of DNA and the symbols of the figure are the same as in Fig. 1. Dotted lines are the results with rifampicin.

syntheses were, however, maxima at $20 \mu \mathrm{M}$ of template when rifampicin was added to the reaction mixture, and the amounts were reduced to a level comparable with those obtained with $\mathrm{Mg}^{2+}$. The maximal incorporation occurred at $20 \mu \mathrm{M}$ of template, when $\mathrm{Mg}^{2+}, \mathrm{Co}^{2+}$, or $\mathrm{Ba}^{2+}$ was used as a cofactor. The addition of rifampicin did not inhibit the synthesis of DNA with these metals.

\section{Kinetics of DNA synthesis}

Time courses of DNA synthesis with these metals were examined using $100 \mu \mathrm{M}$ of M13 and $\phi \mathrm{X} 174$ DNA as template. The results are shown in Figs. $3 \mathrm{a}$ and $3 \mathrm{~b}$.

Phage M13 DNA as template (Fig. 3a). Maximal incorporation of $\left[{ }^{3} \mathrm{H}\right]-$ dTMP into the acid-insoluble fraction was observed at about 30 min with $\mathrm{Mg}^{2+}$, $\mathrm{Mn}^{2+}, \mathrm{Co}^{2+}$, and $\mathrm{Ba}^{2+}$, but with $\mathrm{Sr}^{2+}$, the synthesis of DNA continued slowly for more than $90 \mathrm{~min}$. When $\mathrm{Mn}^{2+}$ was used as a cofactor, the rate and extent of DNA synthesis exceeded those with $\mathrm{Mg}^{2+}$.

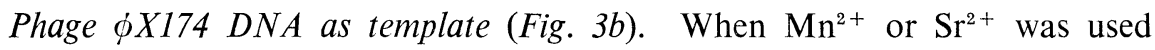
as a cofactor, the rate and extent of DNA synthesis were much greater than those with $\mathrm{Mg}^{2+}$. The extra incorporation obtained with these metals was, however, diminished to a level comparable with that gained with $\mathrm{Mg}^{2+}$ when rifampicin 


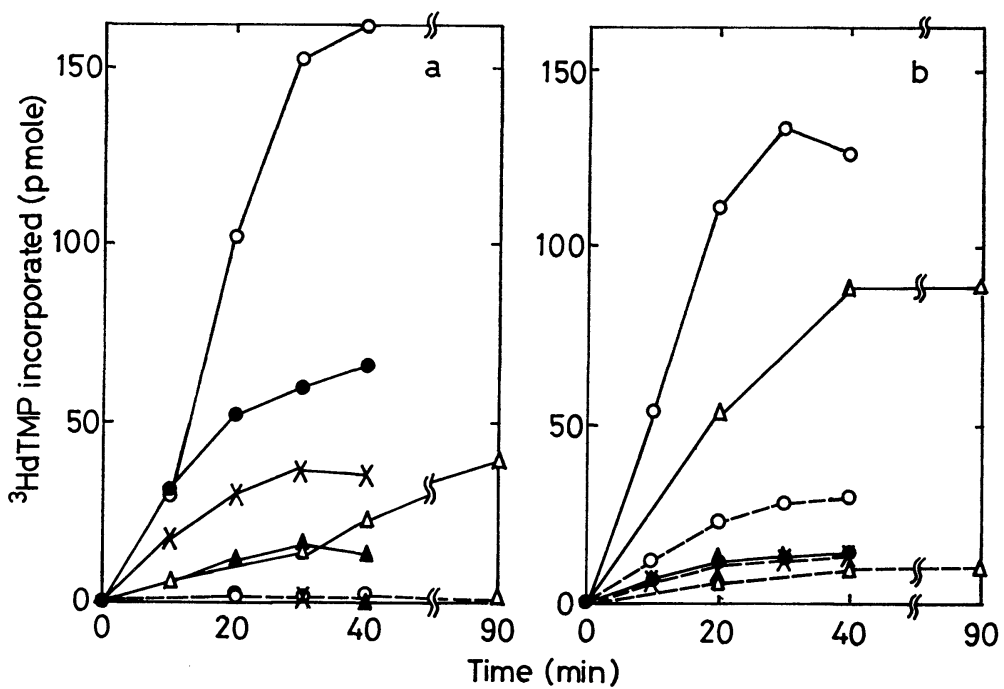

Fig. 3. Time course experiments of the synthesis of DNA.

The incorporation of $\left[{ }^{3} \mathrm{H}\right]$-dTMP into acid-insoluble fraction was measured at the indicated times at the optimal concentration of each metal salts and $100 \mu \mathrm{M}$ of template DNA. a) Phage M13 DNA as template. b) Phage $\phi$ X174 DNA as template. Symbols are the same as in Fig. 1. Dotted lines are the results with rifampicin.

was added.

Centrifugal analysis of M13 DNA synthesized with several divalent cations

i) Sucrose gradient centrifugations. DNA synthesized with M13 DNA as template was analyzed with alkaline sucrose gradient centrifugations. The results were shown in Figs. $4 \mathrm{a}$ and $4 \mathrm{~b}$. DNA synthesized with any metal ion $\left(\mathrm{Mg}^{2+}\right.$, $\mathrm{Mn}^{2+}, \mathrm{Co}^{2+}$, or $\mathrm{Sr}^{2+}$ ) was the intact linear form of M13 DNA, when the concentration of template was $20 \mu \mathrm{M}$ (Fig. 4a). When the concentration of template was $100 \mu \mathrm{M}$, the length of molecules synthesized with $\mathrm{Mn}^{2+}$ or $\mathrm{Sr}^{2+}$ was shorter (about one-third) than template, but not with $\mathrm{Mg}^{2+}$ or $\mathrm{Co}^{2+}$ (Fig. 4b).

The short molecules obtained with $\mathrm{Mn}^{2+}$ or $\mathrm{Sr}^{2+}$ could be due to the hydrolysis of ribonucleotides incorporated into DNA chain during the centrifugation in alkaline solution. The following results suggested that the shortness of the products was genuine and would not be due to the hydrolysis by alkali. The hydrolysis of the products in $0.3 \mathrm{~N} \mathrm{NaOH}$ at $37^{\circ}$ for $18 \mathrm{hr}$ did not affect the size (Fig. 4b) and their heat denaturation produced the shortness in neutral sucrose gradient spin. Although the lengths of the products with $\mathrm{Mn}^{2+}$ or $\mathrm{Sr}^{2+}$ were shorter than those of template after denaturation, they showed the intact doublestranded open circular forms when analyzed in neutral sucrose gradient centrifugation under nondenaturing conditions (see Fig. 6b).

ii) $\mathrm{Cs}_{2} \mathrm{SO}_{4}-\mathrm{HgCl}_{2}$ density gradient centrifugation. The results shown above 


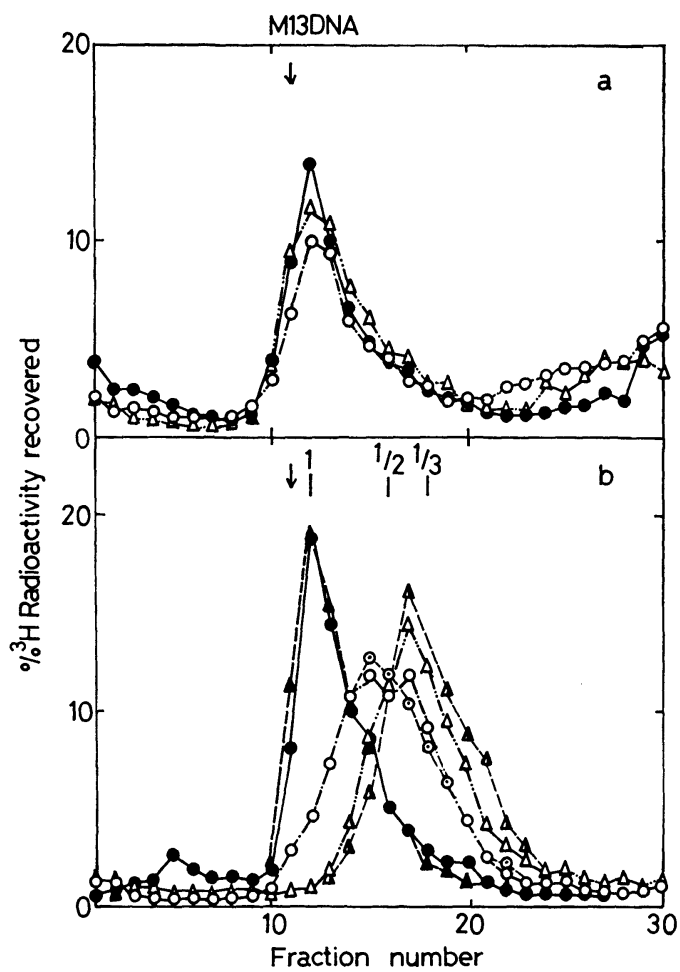

Fig. 4. Alkaline sucrose gradient centrifugation of the DNA synthesized with M13 DNA as template.

DNA synthesized with each metal salt was centrifuged in 5-20\% alkaline sucrose gradient which contained $0.2 \mathrm{~N} \mathrm{NaOH}, 0.8 \mathrm{M} \mathrm{NaCl}$, and $1 \mathrm{~mm}$ EDTA at 33,000 rpm for $16 \mathrm{hr}$ at $4^{\circ}$ with Hitachi RPS55 rotor. After the spin, fractions were collected from the bottom of the tube and acid-insoluble radioactivity was measured as described in MATERIALS AND METHODS. An arrow indicates the position of intact M13 DNA, and the lines numbered $1,1 / 2$, and $1 / 3$ indicate the relative sizes of the DNA calculated (23). a) Results with $20 \mu \mathrm{M}$ of M13 DNA as template. (Results with $20 \mu \mathrm{M}$ of $\phi \mathrm{X} 174 \mathrm{DNA}$ as template were essentially the same as those with M13 DNA. b) Results with $100 \mu \mathrm{M}$ of M13 DNA as template. @, DNA synthesized with $\mathrm{MgCl}_{2} ; \bigcirc, \mathrm{DNA}$ synthesized with $\mathrm{MnCl}_{2} ; \Delta$, DNA synthesized with $\mathrm{CoCl}_{2} ; \Delta$, DNA synthesized with $\mathrm{SrCl}_{2} ; \odot$, centrifugation of DNA synthesized with $\mathrm{MnCl}_{2}$ after $18 \mathrm{hr}$ incubation at $37^{\circ}$ in $0.3 \mathrm{~N} \mathrm{NaOH} ; \boldsymbol{\Lambda}$, centrifugation of DNA synthesized with $\mathrm{SrCl}_{2}$ after $18 \mathrm{hr}$ incubation at $37^{\circ}$ in $0.3 \mathrm{~N} \mathrm{NaOH}$

suggested that the molecules synthesized with $\mathrm{Mn}^{2+}$ or $\mathrm{Sr}^{2+}$ had intact duplex structures and had few gaps, even if the lengths of DNA synthesized were shorter than those of template DNA. In order to confirm the absence of gaps, the molecules synthesized with $\mathrm{Mn}^{2+}$ or $\mathrm{Sr}^{2+}$ were analyzed with $\mathrm{Cs}_{2} \mathrm{SO}_{4}-\mathrm{HgCl}_{2}$ density gradient centrifugation (28). The result is shown in Fig. 5. It is clear that every 


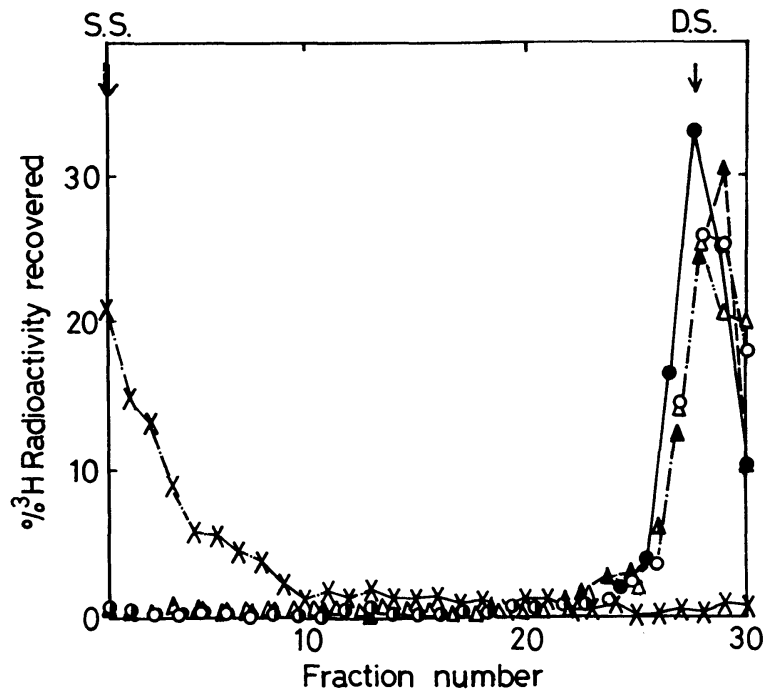

Fig. 5. $\mathrm{Cs}_{2} \mathrm{SO}_{4}-\mathrm{HgCl}_{2}$ density gradient centrifugation.

DNA synthesized with $100 \mu \mathrm{M}$ of M13 DNA and one of the four metal salts was centrifuged in $\mathrm{Cs}_{2} \mathrm{SO}_{4}-\mathrm{HgCl}_{2}$ as described in MATERIALS AND METHODS. An arrow with S.S. indicates the position of single-stranded DNA $(-\cdot-\times-\cdot-)$ and the arrow with D.S. indicates the position of duplex DNA. Other symbols are the same as in Fig. 4.

DNA had the same density as that of the intact duplex molecule, suggesting the absence of gaps.

\section{Integrity of template DNA}

Integrity of template DNA during the synthesis of DNA with $\mathrm{Mn}^{2+}$ or $\mathrm{Sr}^{2+}$ was examined following the method described previously (23), as the shortness of DNA synthesized with $\mathrm{Mn}^{2+}$ or $\mathrm{Sr}^{2+}$ might be due to the fragmentation of template molecule during incubation. The result showed that there was essentially no fragmentation of the template with either metal.

Analysis of DNA synthesized with $\phi X 174$ DNA as template

As shown in Table 1, Figs. 1b, 2b, and 3b, the synthesis of DNA was observed with $\mathrm{Mg}^{2+}, \mathrm{Mn}^{2+}, \mathrm{Co}^{2+}, \mathrm{Sr}^{2+}$, and $\mathrm{Ba}^{2+}$. The structures of DNA synthesized with $\mathrm{Mn}^{2+}$ were compared with those with $\mathrm{Mg}^{2+}$ by alkaline and neutral sucrose gradient centrifugations. The results with $100 \mu \mathrm{M}$ of template DNA are shown in Fig. 6a. The size of DNA synthesized with $\mathrm{Mg}^{2+}$ remained intact whether or not DNA was synthesized in the presence of rifampicin. When $\mathrm{Mn}^{2+}$ was used as a cofactor, the lengths of the product were shorter than those of template, as was the case with M13 DNA (Fig. 4b). The main product, however, had intact length when rifampicin was added to the reaction mixture even with $\mathrm{Mn}^{2+}$. The DNA synthesized with $\mathrm{Mg}^{2+}$ or $\mathrm{Mn}^{2+}$ had intact size when the concentration of 


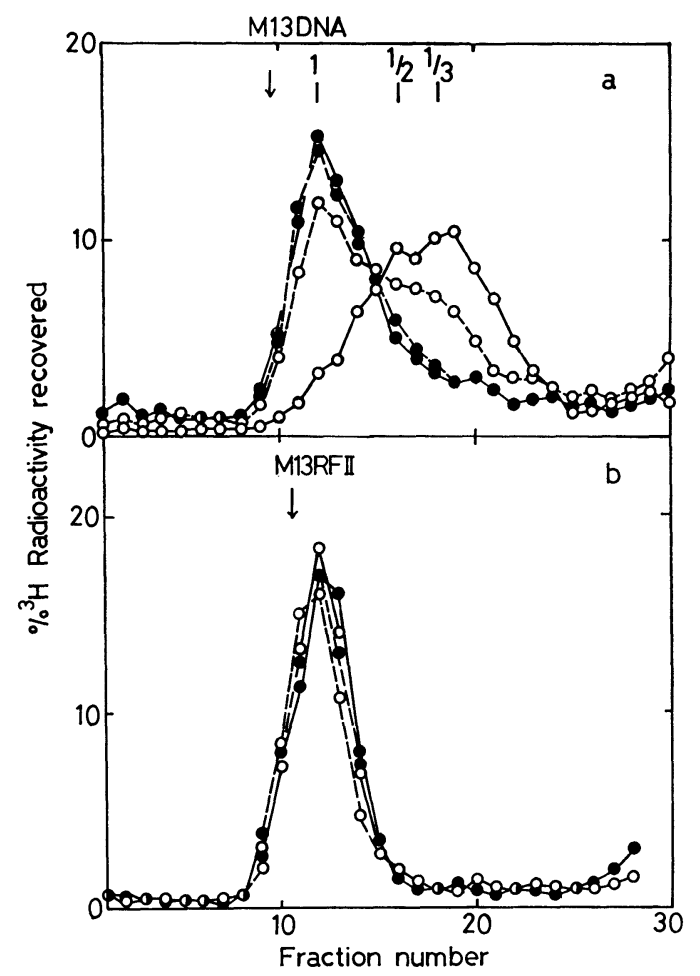

Fig. 6. Centrifugal analysis of DNA synthesized with $100 \mu \mathrm{M}$ of $\phi$ X174 DNA as template.

An arrow indicates the position of intact M13 DNA, and the lines numbered 1, 1/2, and $1 / 3$ indicate the relative sizes of the DNA calculated. a) DNA was synthesized with $\mathrm{MgCl}_{2}$ or with $\mathrm{MnCl}_{2}$ in the presence or absence of rifampicin. It was centrifuged in alkaline sucrose gradient as described in Fig. 4. b) DNA was centrifuged in neutral sucrose gradient as described previously (23). (DNA synthesized with $100 \mu \mathrm{M}$ of M13 DNA gave essentially the same pattern as shown here with $\phi$ X174 DNA.) $\bullet$, DNA synthesized with $\mathrm{MgCl}_{2}$; ------, DNA synthesized with $\mathrm{MgCl}_{2}$ in the presence of rifampicin $\bigcirc$, DNA synthesized with $\mathrm{MnCl}_{2}$; - - , DNA synthesized with $\mathrm{MnCl}_{2}$ in the presence of rifampicin.

template was $20 \mu \mathrm{M}$ (see Fig. 4a). All of these molecules showed intact doublestranded forms, when centrifuged in neutral sucrose gradient (Fig. 6b).

\section{Induction of mutation by divalent cations}

Mutagenic effects of metals were examined with the DNA synthesized with $\mathrm{Mn}^{2+}, \mathrm{Co}^{2+}$, and $\mathrm{Sr}^{2+}$. The duplex DNAs of phage M13 synthesized with these metal ions in the extracts of E. coli $\mathrm{H} 560$ were purified by sucrose gradient centrifugation and the plaque-forming abilities of these molecules were assayed by plating them with $E$. coli $\mathrm{HfrC}$ treated with $\mathrm{CaCl}_{2}$. The induction of clear plaque mutants was measured from the plaques which appeared on the plates. The meas- 
Table 2. Clear plaque mutants in RFII molecule synthesized with various metal salts and phage M13 DNA as template.

\begin{tabular}{|c|c|c|c|}
\hline \multirow{2}{*}{ Metal salt } & I & II & $\mathrm{II} / \mathrm{I}$ \\
\hline & $\begin{array}{l}\text { Number of plaques } \\
\text { per nmol of DNA }\end{array}$ & $\begin{array}{l}\text { Number of clear plaques } \\
\text { per nmol of DNA }\end{array}$ & $\begin{array}{l}\text { Mutation } \\
\text { frequencies }\end{array}$ \\
\hline $\mathrm{MgCl}_{2}$ & $4.1 \times 10^{4}$ & $1.6 \times 10^{2}$ & $3.9 \times 10^{-3}$ \\
\hline $\mathrm{MnCl}_{2}$ & $2.2 \times 10^{4}$ & $6.4 \times 10^{2}$ & $29.4 \times 10^{-3}$ \\
\hline $\mathrm{CoCl}_{2}$ & $2.4 \times 10^{4}$ & $3.8 \times 10^{2}$ & $15.6 \times 10^{-3}$ \\
\hline $\mathrm{SrCl}_{2}$ & $1.6 \times 10^{4}$ & $1.1 \times 10^{2}$ & $6.4 \times 10^{-3}$ \\
\hline
\end{tabular}

DNA synthesized with various metal salts and phage M13 DNA as template was purified by sucrose gradient centrifugation as described in MATERIALS AND METHODS. The plaqueforming activity of the DNA was measured by plating with $E$. coli $\mathrm{HfrC}$ treated with $\mathrm{CaCl}_{2}$. Clear plaques appeared on the plates were counted as forward mutation.

urements of reversion frequencies of amber mutants of phage M13 were unsuccessful due to the high frequencies of spontaneous reversions. The result was summarized in Table 2. Plaque-forming ability of the DNA synthesized with $\mathrm{Mn}^{2+}, \mathrm{Co}^{2+}$, or $\mathrm{Sr}^{2+}$ was about half that of the DNA synthesized with $\mathrm{Mg}^{2+}$. The DNA synthesized with $\mathrm{Mn}^{2+}$ or $\mathrm{Co}^{2+}$, but not with $\mathrm{Sr}^{2+}$, gave higher mutation frequencies than with $\mathrm{Mg}^{2+}$.

\section{DISCUSSION}

Even though a fairly high concentration of magnesium was detected in the extracts of $E$. coli $\mathrm{H} 560$ grown in L-broth, the replication of phage M13 or $\phi$ X174 DNA could not be recognized without the addition of divalent metal salts to the reaction mixture. The magnesium in the extracts would tightly bind to the cell components and could not act as a cofactor.

Several divalent cations other than $\mathrm{Mg}^{2+}$ could function as a cofactor for the synthesis of DNA (Table 1). It would, however, be hard to conclude that the synthesis of DNA occurred solely with these metal ions, as the extracts contained magnesium. Although the metal salts used in this experiment contained a small quantity of impurities (less than $2 \%, w / w)$, the synthesis of DNA observed with some metals would not be due to the impurities, since each metal showed a specific effect on the synthesis of DNA.

Since the gene products required for the conversions of phage M13 and $\phi$ X174 DNA to their replicative forms were not the same (1), the effects of metals were examined with DNA of both phages. The effects of metals other than $\mathrm{Mg}^{2+}$ on the synthesis of DNA with M13 DNA as template can be summarized as follows:

i) With any metal salt, the synthesis of DNA would be primed by the RNA synthesized by RNA polymerase, since the synthesis of DNA was inhibited by rifampicin. 
ii) With $\mathrm{Sr}^{2+}$, the rate of DNA synthesis was slower than that with other metal ions. With $\mathrm{Co}^{2+}$, the synthesis of DNA was poor and the optimal concentration was low. With $\mathrm{Mn}^{2+}$, the rate and extent of DNA synthesis exceeded those with $\mathrm{Mg}^{2+}$ at the optimal concentration. The amount of DNA synthesized increased proportionally with the concentration of template at least up to $100 \mu \mathrm{M}$.

iii) Analysis of the structures of DNA synthesized with these metals gave the following results: DNA synthesized with $\mathrm{Mg}^{2+}$, or $\mathrm{Co}^{2+}$ had intact length. The structure of DNA synthesized with $\mathrm{Mn}^{2+}$, or $\mathrm{Sr}^{2+}$ with $100 \mu \mathrm{M}$ of template was different from that synthesized at $20 \mu \mathrm{M}$. The product was shorter than template at the former concentration and it had intact size with the latter condition. The production of short molecules with these metals were neither due to the fragmentation of template during the incubation nor the hydrolysis of the products during the alkaline sucrose gradient centrifugation. The short fragments would be produced by the initiations of DNA synthesis at several points on the identical template.

The conversion of phage M13 DNA to its replicative form depends not only on DNA polymerase III but on other proteins (18-20). The effect of metal salts on RNA polymerase which requires divalent cations for its activity will also affect the synthesis of DNA. The effects of divalent cations on the synthesis of RNA in the extracts of E. coli H560 under the same condition for the synthesis of M13 DNA was examined. The result showed that the amount of RNA synthesized with $\mathrm{Mn}^{2+}$ was much higher than that with other metal salts, when the concentration of template was $100 \mu \mathrm{M}$. The stimulation of RNA synthesis with $\mathrm{Mn}^{2+}$ might be responsible for the multiple initiations of DNA synthesis.

The results with $\phi \mathrm{X} 174$ DNA as template were essentially the same as those with M13 DNA, with the exception of the effect of rifampicin. With $\mathrm{Mg}^{2+}$, the synthesis of $\phi$ X174 DNA was initiated by primase encoded by gene "dnaG," and it was not inhibited by rifampicin $(19,29,30)$. With $\mathrm{Mn}^{2+}$ or $\mathrm{Sr}^{2+}$, however, the synthesis was not necessarily dependent on dnaG, as demonstrated by the partial inhibition by rifampicin. The synthesis of DNA could be initiated both with primase and with RNA polymerase at several points on the template molecule.

There might be some factors in the extract which could work cooperatively with $\mathrm{Mg}^{2+}$, a natural cofactor, to regulate the initiation of DNA synthesis at a single-specific site per template DNA. When $\mathrm{Mn}^{2+}$ or $\mathrm{Sr}^{2+}$ was used and the concentration of template molecule was high, however, such regulation did not work and the synthesis could be initiated at several points on the template by RNA polymerase.

A preliminary analysis of DNA synthesized with $\mathrm{Ba}^{2+}$ using phage M13 DNA as template by sucrose gradient centrifugation suggested that the synthesis of DNA stopped prematurely, leaving an unreplicated region on the template even at $20 \mu \mathrm{M}$ of template. Each metal seems to have its own specific effect on the synthesis of DNA. 
Several divalent metal ions including $\mathrm{Mn}^{2+}$ and $\mathrm{Co}^{2+}$ are known to be mutagens or carcinogens (31). The mutagenic effects of divalent cations on the DNA synthesized with M13 DNA as template in the extracts of $E$. coli H560 were examined. The result (Table 2) suggested that $\mathrm{Mn}^{2+}$ and $\mathrm{Co}^{2+}$ but not $\mathrm{Sr}^{2+}$ were mutagenic, probably stimulating the incorporation of mismatched nucleotides into the DNA chain. The interruptions present in the DNA synthesized with $\mathrm{Mn}^{2+}$ or $\mathrm{Sr}^{2+}$ would have little effect on the plaque-forming activity and the induction of mutations, for the plaque-forming efficiencies of the DNA synthesized with $\mathrm{Mn}^{2+}$, $\mathrm{Co}^{2+}$, or $\mathrm{Sr}^{2+}$ were almost the same and the DNA synthesized with $\mathrm{Co}^{2+}$ which had no interruption received mutations, whereas the DNA synthesized with $\mathrm{Sr}^{2+}$ where interruptions would be present did not show any meaningful increase of mutation frequency.

Part of this work was supported by a Grant-in-Aid for scientific research from the Ministry of Education, Science and Culture of Japan.

\section{REFERENCES}

1) A. Kornberg, DNA Synthesis, Freeman, San Francisco, p. 65, 218 (1974).

2) M. Demerec and J. Hanson, Cold Spring Harbor Symp. Quant. Biol., 16, 215 (1951).

3) H. Böнme, Biol. Zentralbl., 80, 5 (1961).

4) A. Orgel and L. E. Orgel, J. Mol. Biol., 14, 453 (1965).

5) Z. W. Hall and I. R. Lehman, J. Mol. Biol., 36, 321 (1968).

6) J. H. Van de Sands, P. C. Loewen, and H. G. Khorana, J. Biol. Chem., 247, 6140 (1972).

7) M. A. Sirover and L. A. LoeB, J. Biol. Chem., 252, 3605 (1977).

8) M. A. Sirover, D. K. Dube, and L. A. Loeb, J. Biol. Chem., 254, 107 (1979).

9) M. A. Sirover and L. A. Loeb, Proc. Natl. Acad. Sci. U.S.A., 73, 2331 (1976).

10) M. A. Sirover and L. A. Loeb, Science, 194, 1434 (1976).

11) L. A. Weymouth and L. A. Loeb, Proc. Natl. Acad. Sci. U. S. A., 75, 1924 (1978).

12) T. A. Kunkel and L. A. LoeB, J. Biol. Chem., 254, 5718 (1979).

13) P. BERG, In Informational Macromolecules, ed. by H. J. VOGEL, V. BRyson, and J. O. LAMPEN, Academic Press, New York and London (1963), p. 467.

14) T. Kornberg and M. L. Gefter, J. Biol. Chem., 247, 5369 (1972).

15) D. M. Livingston and C. C. Richardson, J. Biol. Chem., 250, 470 (1975).

16) M. L. Gefter, Y. Hirota, T. Kornberg, J. A. Wechsler, and C. Barnoux, Proc. Natl. Acad. Sci. U. S. A., 68, 3150 (1971).

17) R. C. TAit, A. L. Harris, and D. W. Smith, Proc. Natl. Acad. Sci. U. S. A., 71, 675 (1974).

18) A. Klein and F. Bonhoeffer, Annu. Rev. Biochem., 41, 301 (1972).

19) W. T. Wickner, D. Brutlag, R. Schekman, and A. Kornberg, Proc. Natl. Acad. Sci. U. S. A., 69, 965 (1972).

20) R. B. Wickner, W. Wright, S. Wickner, and J. Hurwitz, Proc. Natl. Acad. Sci. U. S. A., 69, 3233 (1972).

21) Y. Masamune and C. C. Richardson, J. Biol. Chem., 252, 8498 (1977).

22) R. L. Sinsheimer, In Procedures in Nucleic Acid Research, ed. by G. L. Cantoni and D. R. Davis, Harper and Row, New York (1966), p. 569.

23) Y. MaSAMune, Mol. Gen. Genet., 149, 335 (1976).

24) M. Oishi, Proc. Natl. Acad. Sci. U.S.A., 60, 691 (1968).

25) S. N. Cohen, A. C. Y. Chang, and L. Hsui, Proc. Natl. Acad. Sci. U.S.A., 69, 2110 (1972). 
26) O. H. Lowry, N. J. Rosebrough, A. L. Farr, and R. J. Landall, J. Biol. Chem., 193, 265 (1951).

27) A. Sippel and G. Hartmann, Biochim. Biophys. Acta, 157, 218 (1968).

28) U. S. NANDI, J. C. WANG, and N. Davidson, Biochemistry, 4, 1687 (1965).

29) K. Zechel, J.-P. Bouché, and A. Kornberg, J. Biol. Chem., 250, 4684 (1975).

30) J.-P. Bouché, K. ZeChel, and A. Kornberg, J. Biol. Chem., 250, 5995 (1975).

31) F. W. Sunderman, Jr., Adv. Mod. Toxicol., 2, 257 (1977). 